\title{
Dostoiévski e o ressentimento na filosofia de Nietzsche: Alguns apontamentos a partir de Crime $e$ Castigo
}

\author{
Dostoiévski and resentment in Nietzsche's philosophy: Some notes \\ regarding Crime and Punishment
}

\author{
Luis Francisco Fianco Dias \\ fcofianco@gmail.com
}

(Universidade de Passo Fundo, Passo Fundo, Brasil)

\begin{abstract}
Resumo: 0 presente texto tem como objetivo recuperar o conceito de ressentimento na narrativa do romance de Dostoiévski Crime $e$ Castigo e aproximá-lo da conceitualização do ressentimento no pensamento de Nietzsche, mediante igualmente a contribuição da psicanálise. Para tanto, utilizaremos, além do texto de Dostoiévski citado e da obra Genealogia da Moral, entre outras de Nietzsche, o estudo recente sobre o ressentimento na intersecção da filosofia e da psicanálise de Maria Rita Kehl, Ressentimento, entre outros textos. Em função das diversas intersecções possíveis entre Dostoiévski e Nietzsche, nosso estudo não tem a intenção de exaurir o tema, e sim de, ao mesmo tempo que nos permita estabelecer conexões entre os dois autores, poder acrescentar algo ao estudo da interseção de ambos.
\end{abstract}

Palavras-chave: Nietzsche; Dostoiévski; Ressentimento; Crime e Castigo; Genealogia da Moral.

\begin{abstract}
This text aims to recover the concept of resentment in the narrative of Dostoevsky's novel Crime and Punishment and to bring it close to the concept of resentment in Nietzsche's thought, including psychoanalytic contributions. For this purpose, we will use, in addition to the Dostoyevsky's novel named above and Nietzsche's dissertations at Genealogy of Morals, among other texts of the named philosopher, the recent study of resentment at the intersection of philosophy and psychoanalysis by Maria Rita Kehl, Resentment, among other texts. Considering the variety of possible intersections between Dostoyevsky and Nietzsche, our study does not intend to exhaust the topic, but, while allowing us to establish connections between both authors, it aims to add something to the study of this intersection.
\end{abstract}

Keywords: Nietzsche; Dostoyevsky; Resentment; Crime and Punishment; Genealogy of Morals.

\section{Introdução}

- [...] Vê só: eu queria tornar-me um Napoleão e por isso matei... Então, agora dá pra entender?

- N-não [...] (Dostoiévski, 2009, p. 274).

0 ressentimento é um termo da linguagem corrente, um sentimento social e politicamente bastante comum em nossa cultura hoje, não constituindo, portanto, um objeto clássico da investigação filosófica ou mesmo psicanalítica, áreas das 
quais nos valeremos majoritariamente aqui em uma abordagem oriunda dessas duas fontes (Kehl, 2020). Nesse sentido, podemos entender o ressentimento como uma constelação psicológica que de forma muito cara a nossa época serve como mantenimento da individualidade (ou de seu mito) e de reforço às defesas do eu, em especial suas defesas narcísicas. Ou, em outros termos, como um processo mental por meio do qual o sujeito atribui a um outro a responsabilidade máxima por determinada falha ou ruptura, a partir da qual começa a se elaborar fantasiosamente algum tipo de vingança ou reparação que o sujeito ofendido não tem condições de levar a cabo ou que está tão fortemente identificado com essa ofensa que não quer se livrar dela para não ter que despersonalizar-se. "Trata-se de uma repetição mantida ativamente por aquele que foi ofendido. 0 ressentido não é alguém incapaz de esquecer e perdoar; é um que não quer esquecer, ou que quer não esquecer, não perdoar, nem superar o mal que o vitimou” (Kehl, 2020, p. 10, grifo do autor). Podemos ver como o termo faz sentido também em relação ao senso comum que o entende como uma dificuldade de superar uma dor, presentificada em um "resentimento", ou seja, um sentimento que sempre volta. A dinâmica do ressentimento como um "autoenvenenamento psicológico" (Scheler, 1958 apud Kehl, 2020) é a de uma vingança, de uma reação que o sujeito recalca, porque não consegue ou não quer executar, uma vingança cujo tempo nunca chega, pois o ofendido se sente fraco ou impotente em relação ao seu agressor, obrigando toda a hostilidade a se voltar contra si mesmo, como forma de culpabilização e autoacusação, autodepreciação, através de um sentimento inconsciente de culpa. "O vingativo que não se vinga, que espera ser ressarcido pela justiça divina sem se implicar com seu desejo de vingança, se condena ao ressentimento" (Kehl, 2020, p. 17).

Ainda que possa ser satisfatoriamente entendido a partir da psicanálise, a grande referência a respeito do conceito de ressentimento está no pensamento de um filósofo que em diversas passagens se declarava psicólogo, no sentido de ser aquele que tenta entender a alma humana a partir de espectros que outros intelectuais se negariam a levar em consideração. É no pensamento de Nietzsche que encontramos as principais reflexões sobre o ressentimento, e que nos permitem fazer a conexão deste conceito com a narrativa de Dostoiévski (Kehl, 2020). Para o filósofo, o ressentimento é uma característica psicológica dos fracos, daqueles dotados de uma moral reativa e que se ofendem por fazerem de si mesmos uma imagem idealizada, como os bons, os mansos, os perfeitos, que absolutamente não corresponde ao ser humano real. Nessa oposição, que é mais entre os fracos e os fortes do que entre os bons e os maus, os fracos padecem da doença da memória. Junto com a consciência, eles não conseguem esquecer um agravo, e por conta dessa persistência adoecem com a agressividade que não conseguem direcionar para os fortes e terminam por direcioná-la a si mesmos. 
Todos os instintos que não se descarregam para fora voltam-se para dentro - isto é o que eu chamo de interiorização do homem: é assim que no homem cresce o que depois se denomina a sua "alma". [...] A hostilidade, a crueldade, o prazer na perseguição, no assalto, na mudança, na destruição - tudo isso se voltando contra os possuidores de tais instintos: esta é a origem da má consciência (Nietzsche, 2004, p. 73).

O presente texto não tem a intenção de recuperar detalhadamente o romance de Dostoiévski, tampouco traçar todos os paralelos possíveis entre Nietzsche e Dostoiévski, e sim apontar alguns indícios da permanência do ressentimento presente como motivação homicida em Crime e Castigo ecoando como conceito filosófico em Nietzsche e que talvez possa, além de abrir novas frentes de pesquisa, ajudar-nos a entender um pouco melhor o desconforto existencial e o irromper de discursos de agressividades recalcadas e criminosas nesse nosso início de milênio (Marton, 2018, p. 32). Ainda, quanto à grafia dos nomes em russo, uma última observação: adotaremos o padrão utilizado por Paulo Bezerra em sua tradução de Crime e Castigo realizada recentemente diretamente do russo para o português, limpando o texto de influências que ele poderia sofrer em traduções intermediadas por outras línguas modernas e mantendo a crueza deselegante que caracteriza em Dostoiévski a ruptura com o pensamento tradicional e seus cânones estilísticos (Bezerra, 2009).

\section{Crime e Castigo (1866): um tratado sobre o ressentimento}

Crime e Castigo pode ser entendido como uma grande investigação do sentimento de culpa em forma de romance policial, revelando sobre seu autor a influência confessa dos contos policiais de Edgar Alan Poe. Sinteticamente, é a narrativa que mostra como um jovem intelectual miserável e sem perspectivas mata uma velha exploradora e desagradável também para provar a si mesmo um ponto de vista teórico e que depois, angustiado pela culpa, deambula pela cidade de São Petersburgo esbarrando em outros personagens que colocam em dúvida a sua relação com os critérios morais. Por outro lado, é a narrativa que dá conta de uma certa estética do ressentimento, sendo uma das mais complexas reflexões sobre a psicologia do homem ordinário em uma sociedade em transformação das estruturas agrárias tradicionais para a modernidade industrial e urbana na qual as ideias iluministas de igualdade universal vão provocar uma teoria da diferenciação que terá como resultado prático não mais do que um crime insignificante (Kehl, 2020).

O protagonista dessa narrativa específica se chama Raskólnikov, cujo nome inclui a partícula raskól, que significa ruptura, cisão, crise, a partir de uma seita do século XVII que preferiu a perseguição e a deportação a aceitar uma certa interpretação de textos sagrados feita pelo patriarca de Níkone, deixando entrever, portanto, que o personagem é, sobretudo, um cismático, um apartado da comunidade humana 
(Silveira, 1970). Sabemos já desde as primeiras páginas do texto que Raskólnikov é um ex-estudante, intelectual miserável, que se sente explorado e injustiçado em um mundo que não valoriza adequadamente suas habilidades intelectuais (Kehl, 2020).

- Que ela é imbecil, é, assim como eu; agora tu, o que és, um sabichão, que fica aí deitado feito um saco e ninguém te vê fazendo nada? Antes tu dizias que saías a dar aulas a crianças; e agora, por que não fazes nada?

- Eu faço... - pronunciou Raskólnikov sem querer em tom severo.

- O quê?

- Um trabalho...

- Que trabalho?

- Penso - respondeu sério depois de uma pausa.

Nastácia rolou de rir. Era do tipo risonho, e quando a faziam rir, ria sem ser ouvida, arfando e sacudindo o corpo todo, até ficar enjoada (Dostoiévski, 2009, p. 45).

0 personagem chega a manifestar diversas vezes que se sente realmente ofendido, ou seja, sente que o mundo e as pessoas de seu convívio the devem alguma coisa, alguma compensação pelo transtorno de existir. Ao mesmo tempo, ele se compadece dos que mais sofrem e é gentil com os mais humildes, apresentando uma profundidade e multiplicidade em sua caracterização, o que o torna um anti-herói exemplar.

Minha mãe me mandaria para o pagamento das anuidades, e para comprar botas, roupa e comida eu mesmo ganharia; com certeza! Arranjaria aulas; ofereciam cinquenta copeques por aula. [...] Mas eu fiquei furioso e não aceitei. Isso mesmo, furioso (essa palavra é melhor!). Na ocasião eu me encafuei num canto do meu quarto como uma aranha (Dostoiévski, 2009, p. 425, grifo do autor).

Raskólnikov vive da pensão da mãe, já executou pequenas tarefas de tradução e ensino, mas desistiu por não aceitar empregos que julga abaixo de suas qualidades intelectuais superiores (Kehl, 2020). Outrora estudante de direito, agora empenha pequenos objetos para levantar valores irrisórios que gasta imediatamente em bebida, ou mesmo doa a pessoas em necessidade, como a jovem prostituta Sônia e sua família. Em termos de relação afetiva, demonstra um ciúme exacerbado de sua irmã, que está prestes a se casar com um homem financeiramente bem estabelecido, o que facilitaria o mantenimento dos estudos que ele não vem realizando. 0 jovem é a grande aposta da mãe, a única que acredita no potencial do filho, o que percebemos através do orgulho dela pela publicação de um artigo do filho que ela lê e não compreende. Essa mãe, extremamente dedicada e que por ele aceita "sacrificar" a filha, gera em Raskólnikov um sentimento de culpa, criando nele uma expectativa passiva da realização prometida, peso sob o qual vemos o personagem prestes a arrebentar já nas primeiras páginas do livro, assim como a égua que morre de tanto apanhar por não conseguir mover a carga excessiva que the fora imputada, conforme 
ele relata em um sonho. Kehl (2020) lembra, em nota, a proximidade entre o sonho de Raskólnikov com a égua espancada até a morte pelos camponeses bêbados e o desabrochar pleno da loucura de Nietzsche, quando o filósofo, saindo da ópera em Turim, se abraça chorando a um cavalo que estava sendo açoitado pelo cocheiro, em 3 de janeiro de 1888.

Diante da dívida instituída por tão grande aposta, na expectativa de que o mundo reconheça nele o ideal sustentado pelo olhar da mãe, Raskólnikov torna-se ao mesmo tempo pretensioso e fraco. A antecipação materna instalou o filho na espera passiva da realização prometida, na falta da qual Raskólnikov se vê privado de reconhecimento (Kehl, 2020, p. 128).

O personagem vai descortinando-se, assim, nesse emaranhado de sensações contraditórias, palco no qual seu narcisismo autocentrado choca-se com sua inadequação social e seu sentimento de inferioridade, em um conflito pontuado esporadicamente por atos de gentileza e compaixão. O grande desfecho de sua angústia acontece já nas primeiras páginas da obra, momento em que ele realiza o homicídio como forma de comprovação de sua teoria de superioridade moral.

- O que é isso? - perguntou ela, mais uma vez fixando o olhar em Raskólnikov e pesando o penhor na mão.

- Um objeto... uma cigarreira... de prata... dê uma olhada.

- Que coisa, como se não fosse de prata... e como você a amarrou!

[...]

Ele não podia perder mais nem um instante. Tirou o machado por inteiro, levantou-o com as duas mãos, mal se dando conta de si, e quase sem fazer força, quase maquinalmente, baixou-o de costas na cabeça dela. Era como se nesse instante tivesse lhe faltado a força. Mas foi só ele baixar uma vez o machado que lhe veio a força. [...]. Ele estava em plena consciência, já não sentia mais perturbação mental nem vertigem, no entanto as mãos ainda continuavam a tremer. Mais tarde lembrou-se de que esteve inclusive muito atento, cauteloso, procurando sempre evitar manchas... (Dostoiévski, 2009, p. 91-92).

Esse trecho demonstra, a partir de certos detalhes, não apenas a premeditação de Raskólnikov, como o pacote excessivamente embrulhado que lhe daria tempo de acessar o machado que trazia escondido em sua roupa enquanto Aliéna Ivánovna tentava se desvencilhar do embrulho, mas igualmente o autocontrole subsequente ao ato que percebemos no cuidado em evitar manchar-se no sangue que escorria apesar de os golpes terem sido desferidos com o olho do machado e não com sua lâmina. A descrição dos trechos citados e de outros detalhes que não teríamos aqui espaço suficiente para transcrever demonstra tal ação não como um ato impulsivo ou dotado de passionalidade, e sim quase como um experimento moral, conforme as teorias do crime que veremos descritas em seguida. A única coisa que consegue 
quebrar o planejamento é a chegada inoportuna da irmã da vítima:

Súbito soaram passos de alguém no cômodo onde estava a velha. Ele parou e ficou quieto como um morto. Mas tudo estava em silêncio, logo, fora impressão. De repente ouviu-se nitidamente um leve grito, ou como se alguém tivesse dado um gemido baixinho e entrecortado, calando em seguida. [...]. No meio do cômodo estava Lisavieta em pé, com uma trouxa grande na mão, olhando pasma para a irmã morta, inteiramente branca como um pano e sem forças para gritar. [...]. O golpe foi direto no crânio, de lâmina, e de uma só vez abriu toda a parte superior da testa, chegando quase às têmporas. E ela desabou. Raskólnikov estava quase desnorteado; agarrouthe a trouxa, largou-a e correu para a antessala (Dostoiévski, 2009, p. 93-94).

Esse duplo homicídio, de Aliéna Ivánovna e sua irmã Lisavieta, mais comprova uma teoria moral do que traz vantagem material, encenando uma quase gratuidade da violência, contrastando com as formas de explicação do crime como anomalia contemporâneas ao autor, seja a de que a agressividade tem origem na disparidade material (causa sociológica) ou na doença mental (causa médico-científica). Isso reflete na argumentação de Dostoiévski tanto o Materialismo Histórico quanto o Positivismo como formas de explicação última da realidade - ou pelo menos da criminalidade -, ambas correntes muito fortes no pensamento do século XIX, ou mesmo o mecanicismo que lhes antecedeu (Pondé, 2003). Quanto ao Socialismo, temos a crítica de Dostoiévski na voz do personagem Razumíkhin, repetindo argumentos bastante conhecidos nos discursos liberais e republicanos das décadas de 1850 e 1860, de que, apesar do meio social, é necessário que os indivíduos se responsabilizem moralmente por seu comportamento e pelas circunstâncias da vida ao seu redor (Dostoiévski, 2009), em uma simplificação até grosseira da teoria materialista:

Começou com a concepção dos socialistas. Uma concepção conhecida: o crime é um protesto contra a anormalidade do sistema social e só, nada mais, e não se admitem quaisquer outras causas - e nada mais!... [...].

- N-nada mais se admite! - interrompeu entusiasmado Razumíkhin - E não estou mentindo!... Eu te mostro um livro deles: eles defendem tudo isso porque para eles “o indivíduo é vítima de seu meio" e nada mais! É a frase preferida! Daí se deduz diretamente que, caso se construa a sociedade de maneira correta, todos os crimes desaparecerão de um só golpe, uma vez que não haverá contra o que protestar e em um instante todos os homens se tornarão justos (Dostoiévski, 2009, p. 265).

Dostoiévski, com essa crítica, aponta para a insuficiência das explicações causais muito estreitas do comportamento humano transgressor, em especial em relação ao crime, deixando entrever que o labirinto psicológico humano é mais complexo e mais profícuo na criação de seus monstros míticos, ou seja, que talvez a maldade humana não se explique apenas pela carência material ou pela doença mental, e sim por uma tendência humana ao prazer na agressão que, atravessando 
a teoria da Vontade de Potência de Nietzsche, vai ser adequadamente teorizada como Pulsão de Morte no célebre texto de Freud, Além do Princípio de Prazer (1920). Uma das principais características da narrativa de Dostoiévski reside no fato de colocar seus protagonistas à beira de um certo tipo de abismo, para que eles ou retornem seguramente ao consolo da coletividade, a mediocridade da massa de que fala Nietzsche, ou a ultrapassem em um caminho sem possibilidade de retorno, sofrendo inexoravelmente as consequências da ruptura deste limiar (Bakhtin, 1981). Dessa forma, ainda que racionalizado e teorizado, o impulso homicida de Raskólnikov corresponde, de certa maneira, a uma tendência humana inata para a agressão, ajudando a entender a "gratuidade" do crime, ou seja, o fato de que dele não adveio vantagem material alguma.

Efetivamente, pensando assim, percebemos que o crime cometido foi, por um lado, inútil, pois ele mata para provar um certo desprendimento moral que não tem e acaba roubando joias das quais se desfaz para despistar seu homicídio em latrocínio; por outro lado, é um crime reativo (Kehl, 2020), isto é, cometido como forma de justificar psicologicamente a sensação de culpa e inferioridade que o personagem demonstra já desde os primeiros trechos da narrativa. Este ponto é importante: Raskólnikov mata como forma de se livrar do ressentimento, mata para não precisar encarar o fato de que não corresponde ao ideal de superioridade com o qual se identifica ao fabular sua teoria, mata para não ter que reconhecer que a imagem grandiosa feita dele pela mãe não corresponde ao filho real, mata por uma tentativa desesperada de fazer parte do grupo dos homens extraordinários que conceitua em seu artigo.

Aqui nos permitimos uma digressão psicanalítica: não podendo matar a mãe (mulher mais velha que lhe dá dinheiro em troca de uma relação que ele entende como humilhação), ele mata a usurária (igualmente uma mulher mais velha que the dá dinheiro em troca de humilhação). Em ambos os casos, acidentalmente, o ato implica igualmente a eliminação ou o sacrifício da irmã, seja a sua, seja a de Lisavieta, ambas irmãs pelas quais o personagem sente certa forma de atração afetiva ou erótica. Logo, a relação com o parricídio em Irmãos Karamázov, como comentado por Freud (2018), fica aqui antecipada pela realização simbólica de um matricídio premeditado com a morte acidental de uma figura fraternal feminina.

O assassinato covarde e gratuito é uma vingança fora de lugar: Raskólnikov o pratica para provar uma ousadia que não possui, num ato privado do qual não saberá tirar proveito algum. A partir dessa passagem, a longa narrativa de Dostoiévski centra-se sobre o tormento que consome o protagonista, raskol, um homem em cisão consigo mesmo (Kehl, 2020, p. 129).

Após o assassinato a narrativa se desdobra em forma de delírio persecutório 
em uma São Petersburgo onírica, compondo uma narrativa de pesadelo na qual "o super-eu tornou-se sádico; o eu tornou-se masoquista” (Freud, 2018, p. 293), ou seja, vemos um Raskólnikov que perambula por uma cidade caótica e que pede desesperadamente pela punição do crime com o qual se tornara insuportável de conviver, como em uma tentativa desesperada de restauração da ordem moral que deve ligar inexoravelmente o crime e o castigo.

Muito, porém, daquilo que se passa no pensamento de Raskólnikov só nos é acessível através dos embates intelectuais que ele tem com outros personagens que the oferecem a oportunidade de se justificar e desenvolver os seus argumentos. Isso se torna bastante evidente no diálogo que tem com o juiz Porfiri Pietrovitch. Após uma sequência de frases dúbias a partir das quais Raskólnikov se atormenta imaginando se o juiz sabe ou não sabe de sua culpa no assassinato da velha usurária, o juiz chama atenção para o artigo acadêmico publicado pelo jovem ex-estudante. Embora o ponto central do artigo seja a divisão da humanidade em dois tipos, seu conteúdo manifesto é, talvez de forma diversiva, o estado psicológico do criminoso durante o crime, no qual, segundo seu autor, sempre se pode notar a influência de alguma forma de padecimento físico.

- Sim, e o senhor insiste em que o ato de execução de um crime sempre é acompanhado de uma doença. Muito, muito original, no entanto... a mim propriamente não foi essa parte do seu artigo que me interessou e sim um certo pensamento emitido no final do artigo mas que o senhor, infelizmente, desenvolve penas por insinuação, de forma vaga... Numa palavra, se o senhor está lembrado, há certa insinuação ao fato de que existiriam no mundo certas pessoas que podem... ou seja, não é que podem mas têm o pleno direito de cometer toda sorte de desmandos e crimes, como se a lei não houvesse sido escrita para eles (Dostoiévski, 2009, p. 268).

A teoria de Raskólnikov, portanto, realiza uma divisão da humanidade em dois tipos básicos, a dos medíocres, que, por falta de força moral e desprendimento, estão condenados a obedecer às regras morais e uma eterna repetição da tradição, e os mais audazes, entendidos por ele como homens superiores que, por meio da transgressão, são capazes de criar algo novo, de instituir uma nova ordem. Aqui notamos um embrião da divisão nietzschiana da dupla moralidade desenvolvida em Genealogia da Moral, onde, já na primeira dissertação, temos a digressão filológica que vai opor os fortes e potentes aos fracos e limitados, criando uma moralidade dos senhores como moralidade criativa e dinâmica em oposição a uma moralidade reativa dos escravos, também entendida como moralidade de rebanho.

Todos os doentes, todos os doentios, buscam instintivamente organizar-se em rebanho, na ânsia de livrar-se do surdo desprazer e do sentimento de fraqueza: o sacerdote ascético intui esse instinto e o promove; onde há rebanho, é o instinto de fraqueza que o quis, e a sabedoria do sacerdote que o organizou. Pois, atente-se para isso: os fortes buscam necessariamente dissociar-se, tanto quanto os fracos buscam associarse (Nietzsche, 2004, p. 125). 
Estes últimos, os fracos, mais numerosos, realizariam o que Nietzsche chamou de "revolta escrava da moral", num processo que terminaria por condenar aos senhores a sua força, transformando-a em violência e crueldade, e erigindo a fraqueza, a mansidão, a passividade e a obediência como virtudes positivas, ao contrário da negatividade que essas contra-virtudes representavam na moralidade aristocrática inicial. Essa exclusão da maioria estaria na base do ressentimento moral que Nietzsche identifica como uma das mais fortes características da decadência da civilização ocidental e que estaria se acentuando imensamente na modernidade.

Voltando a Raskólnikov: por amor à humanidade, ou, pelo menos, em seu benefício, seria lícito por parte de indivíduos grandiosos o cometimento do crime:

Lembro-me ainda, de que eu desenvolvo em meu artigo a ideia de que todos... [...] todos eles [legisladores] sem exceção, foram criminosos já pelo simples fato de que, tendo produzido a nova lei, com isso violaram a lei antiga que a sociedade venerava como sagrada e vinha dos ancestrais, e aí, evidentemente, não se detiveram nem diante do derramamento de sangue [...]. É até notável que a maioria desses beneméritos e fundadores da sociedade humana foram sanguinários especialmente terríveis (Dostoiévski, 2009, p. 269).

A questão aqui não é tanto o crime por si mesmo, ou a natureza do crime em questão, e sim a possibilidade de transgressão (transvaloração?) da moral, ainda que atravessando a sua objetificação na forma da lei, para a criação de uma nova forma de moralidade ou de organização social, o que, insinua Raskólnikov, vem sendo realizado pelos grandes nomes da história de forma compulsiva. Essa mesma reflexão é retomada por Nietzsche em Crepúsculo dos ídolos, em que o filósofo, ao abordar a constituição sadia que degenera em criminoso apenas por inadequação a uma sociedade adoentada, retoma Dostoiévski como seu antecessor:

O tipo criminoso e o que lhe é aparentado - O tipo criminoso é o tipo de ser humano forte sob condições desfavoráveis, um homem forte que tornaram doente. [...]. É na sociedade, em nossa mansa, mediana, castrada sociedade, que um ser natural, vindo das montanhas ou das aventuras do mar, degenera em criminoso. Ou quase necessariamente: pois existem casos em que um tal homem se revela mais forte do que a sociedade: o corso Napoleão é o mais célebre exemplo. 0 testemunho de Dostoiévski é de importância para o problema que aqui se apresenta (Nietzsche, 2017, p. 78-79, grifo do autor).

A menção a Napoleão, assim como a coincidente teoria da humanidade em dois tipos hierarquizados, por si só, não significa uma afirmação tácita da leitura de Nietzsche do texto de Dostoiévski que apresentamos aqui. Há registros irrefutáveis de que ele teria lido Memórias do subsolo, Escritos da casa morta e Os demônios, mas quanto a outras obras mais célebres do escritor russo, como 0 idiota, Os irmãos Karamázov e, neste caso, em especial, Crime e Castigo, não se pode afirmar nem 
que Nietzsche os tenha lido nem que não os tenha (Paschoal, 2010). O que vale destacar aqui, na verdade, é a filiação temática e a reincidência das questões nos dois autores, na perspectiva de que que aquilo que há de mais sagrado e arcaico, de mais tradicional na composição da moralidade humana assenta suas raízes em eventos hediondos, aproximando mais uma vez a argumentação do personagem de Dostoiévski da reflexão nietzschiana enquanto ambos os precursores do pensamento psicológico em solo europeu (Giacoia Junior, 2001, p. 19).

Ora, é na medida em que fornece material para a caracterização daquele tipo de homem que Dostoiévski se apresenta como uma fonte para Nietzsche e que podem ser indicados pontos de semelhança entre o "homem de consciência hipertrofiada" e o "homem do ressentimento". Assim como o personagem de Dostoiévski, também o tipo que segundo Nietzsche estaria na origem daquela moral não reage de forma efetiva diante das adversidades e também não esquece suas desditas. Também ele termina por reter em si os sentimentos de rancor, o ódio e a sede de vingança advindos daquele quantum de força que deveria ser descarregado para fora e que permanece nele, sendo re-sentido, porém não digerido, ocupando todo o seu mundo interior (Paschoal, 2010, p. 215).

Em Genealogia da Moral, Nietzsche vai retomar o próprio termo ressentimento, que não aparece em seus escritos desde a sua juventude, mais especificamente em 1875, em um ensaio sobre o livro O Valor da Vida, de Eugene Dühring (Paschoal, 2010). Reaparece aqui a divisão da humanidade em dois grupos, o primeiro formado pelos aristocratas, dotados de uma moralidade espontânea e afirmativa, criadora, a moral dos senhores, e um segundo grupo, os fracos e decadentes, submetidos àqueles e que têm no ódio silencioso a sua moralidade. A revolta escrava da moral, operada por esses últimos, estabelecerá a moralidade de rebanho, através da qual a moralidade em geral executará um enfraquecimento da vontade de viver e uma domesticação da humanidade, diminuindo nos homens a força dos instintos, o que os impediria de executar a sua vingança agressiva em direção daqueles que o ofendem, voltando essa agressividade para si em forma de culpabilização, obediência e fortalecimento das exigências de sacrifício da vontade livre e soberana em nome da moral, criando com isso uma nova concepção de sociedade e de justiça que se tem na modernidade (Paschoal, 2010). E esse movimento de recalcamento, da vontade de potência que se volta contra si mesma, é o que estabeleceria na moral dos escravos o traço distintivo do ressentimento: "O ressentimento não é o afeto que caracteriza a posição de todos os derrotados; só daqueles que, por motivos morais, foram covardes e cúmplices de sua própria derrota” (Kehl, 2020, p. 71).

A rebelião escrava na moral começa quando o próprio ressentimento se torna criador e gera valores: o ressentimento dos seres aos quais é negada a verdadeira reação, a dos atos, e que apenas por uma vingança imaginária obtêm reparação (Nietzsche, 2004, p. 28). 
Esse é o processo pelo qual os valores morais, sempre uma fabulação humana imanente, são impostos pelos mais fracos sobre os mais fortes, pela dimensão sutil da culpa. Aqui fica claro que o critério de diferenciação entre fracos e fortes é uma questão psicológica, e que não é estática, ou seja, não tem a ver com o pertencimento de grupo, e sim com a atitude frente a existência. Isso faz com que a vida seja o valor de afirmação a partir do qual as duas moralidades podem ser cotejadas: ao passo que a moral dos escravos é uma negação do sofrimento e com ele da vida, a moral aristocrática é uma afirmação da vida e uma forma de permitir que ela se expanda e se afirme sempre mais.

Supondo que fosse verdadeiro o que agora se crê como "verdade", ou seja, que o sentido de toda a cultura é adestrar o animal de rapina "homem", reduzi-lo a um animal manso e civilizado, doméstico, então deveríamos sem dúvida tomar aqueles instintos de reação e ressentimento, com cujo auxílio foram finalmente liquidadas e vencidas as estirpes nobres e os seus ideais, como os autênticos instrumentos da cultura (Nietzsche, 2004, p. 33).

Na sua incapacidade de ação e mesmo de reação, o ressentido experimenta o sentimento de culpa por se reconhecer corresponsável pela ofensa a partir da qual se percebe. "O ressentimento é o predomínio das forças reativas sobre as forças ativas. 0 ressentido é alguém que nem age nem reage realmente; produz apenas uma vingança imaginária, um ódio insaciável” (Machado, 2001, p. 61). O ressentimento nasce justamente da incapacidade de cobrança dessa dívida por causa da negação que o ressentido faz da sua capacidade agressiva e do seu gosto pela crueldade, instituindo o mecanismo imparcial da justiça, ainda que fantasiada, no lugar de uma palpável vingança como ato pessoal (Kehl, 2020).

Esse desejo de vingança recusado é o núcleo doentio do pensamento nietzschiano. Uma vez que não se permite reagir, só resta ao fraco ressentir. 0 ressentimento é uma doença que se origina do retorno dos desejos vingativos sobre o eu. É a fermentação da crueldade adiada, transmutada em valores positivos, que envenena e intoxica a alma, condenando-a ao não esquecimento (Kehl, 2020, p. 74, grifo do autor).

Ao entendermos o ressentimento como uma incapacidade de vingança, podemos perceber o ideal ascético como uma elaboração argumentativa do ressentimento, ou, dito de outra forma, a elevação do ressentimento de afecção individual à visão de mundo, o ressentimento como cosmovisão (Onfray, 2005). O ressentimento gerado por este ascetismo seria, portanto, uma espécie de doença, um padecimento de escassez de potência associado a uma incapacidade de esquecer: "Uma vez minada a força plástica do esquecimento, o sofredor torna-se incuravelmente ressentido". (Giacoia Junior, 2005, p. 120). Ao postular por meio do ascetismo a primazia de um outro mundo em detrimento desta realidade vivida, o asceta está dizendo que não suporta essa realidade e precisa criar o refúgio fantasioso do além-mundo como 
uma espécie de fuga capaz de realizar esta vingança que ele não se permite. "O objetivo do ideal ascético é transformar o ativo em culpado" (Kehl, 2020, p. 75). E essa transformação tem como objetivo impedir que o forte exerça sua força e com isso desmascare a impotência dos demais, para que todos uniformemente se regozijem com a esperança da derradeira vingança que será magicamente realizada para restaurar a bela imagem de si mesmos feita pelos ressentidos, vinculando mais uma vez o ressentimento ao narcisismo, ao ódio contra tudo aquilo que é não-eu (Kehl, 2020), e trazendo a justiça e o reconhecimento dos bons e mansos, como já foi destacado acima:

Todos os doentes, todos os doentios, buscam instintivamente organizar-se em rebanho, na ânsia de livrar-se do surdo desprazer e do sentimento de fraqueza. 0 sacerdote ascético intui esse instinto e o promove; onde há rebanho, é o instinto de fraqueza que o quis, e a sabedoria do sacerdote que o organizou (Nietzsche, 2004, p. 125).

Estabelecidos esses paralelos, percebemos como a narrativa de Dostoiévski realiza e antecipa o ideal nietzschiano do super-homem como transvaloração dos valores e ultrapassagem da moralidade judaico cristã. Nessa passagem, e aqui se nota claramente uma crítica do escritor russo ao estabelecimento artificial e exótico de uma moralidade europeia sobre a sociedade russa, fica claro que a autonomia racional do dever kantiano, que vem substituir a heteronomia moral da religião, não parece forte o suficiente para passar a fundamentar a universalidade moral das interdições. Ainda que passe um tempo debatendo-se no vazio do niilismo, a narrativa parece sugerir o retorno aos valores religiosos tradicionais russos como forma de aplacar esta inquietação do sentido, conforme veremos em seguida.

Uma vez que nos foi esclarecida a teoria sobre os homens superiores a partir de seu artigo de jornal, podemos entender a angústia de Raskólnikov em relação não apenas ao crime cometido, como também no que diz respeito ao casamento da irmã. Se por um lado ele não passou a pertencer ao grupo de homens superiores por ter matado Aliena Ivánovna e sua irmã, Lisavieta, entendidas como pessoas inferiores que poderiam ser tranquilamente sacrificadas em prol de um bem maior para a humanidade, tampouco nosso anti-herói consegue aceitar que o sacrifício de uma pessoa ordinária possa se dar na pessoa de sua própria irmã, prestes a ser imolada no altar nupcial por interesses econômicos da mãe, que tem como última intenção o mantenimento da possibilidade do filho continuar estudando e alcançar o futuro brilhante que ela "sabe" que ele merece (Kehl, 2020). Justamente o que pode salvar Raskólnikov é o que ele mais despreza: o sacrifício das pessoas humildes e comuns a favor de seus entes queridos, nesse caso, em especial o casamento da irmã amada com um burguês emergente, um nouveau rich, representante do materialismo comercial que ele, enquanto intelectual um tanto idealista, despreza. Assim fica comprovada a falência de sua teoria ou, pelo menos, a sua exclusão do 
grupo dos homens superiores como Napoleão, na medida em que sua vida não seja efetivamente extraordinária, ela não vale o sacrifício de milhares de medíocres, não vale, nem mesmo, o sacrifício da felicidade da irmã, o que só vem para aumentar sua sensação de culpa e inferioridade e, com isso, seu ressentimento.

A saída desse imobilismo causado pela culpa parece surgir a partir da relação com Sônia, que Raskólnikov conhece no início da narrativa por meio do pai desta, companheiro de bebida em uma taverna que ele ajuda a chegar em casa e que, depois, atropelado e morto por uma carruagem, tem a família amparada por Raskólnikov com o valor necessário para a realização da recepção e dos ritos fúnebres.

Um sentimento que ele já não conhecia há muito tempo desabou como uma onda em sua alma e a abrandou de uma vez. Ele não the ofereceu resistência: duas lágrimas the rolaram dos olhos e ficaram suspensas nos cílios.

- Então não vais me deixar, Sônia? - falou, olhando-a quase com esperança.

- Não, não; nunca e em nenhum lugar! - exclamou Sônia. - Vou te acompanhar, vou a toda parte. Ô deus!... Oh, eu sou uma infeliz!... [...]

- Agora! Oh, o que fazer agora!... Juntos, juntos! - repetia ela como quem devaneia e tornava a abraça-lo. - Irei para os campos de trabalhos forçados junto contigo! (Dostoiévski, 2009, p. 421).

Esta menina, de uma religiosidade piedosa, ingênua e sincera, que se prostitui em sacrifício do bem-estar da família composta pela mãe agora viúva e pelas irmãs mais novas, representa a humanidade miserável e ofendida, mas que mantem a possibilidade de esperança através da redenção religiosa, exemplificada na relação entre ela e Raskólnikov pela personagem de Lázaro, que é milagrosamente ressuscitado por Jesus (Kehl, 2020). "Para a fisiologia de Nietzsche, a eficácia do fatalismo russo consiste em que, com ele, supera-se o ressentimento pela mais curiosa das medicações: o amor fati" (Giacoia Junior, 2005, p. 126, grifo do autor). Essa tácita aceitação da realidade, essa forma de amor fati aqui representada por Sônia, é igualmente a receita de Nietzsche para vencer o ressentimento como doença, possibilitando o que Nietzsche vai chamar de "grande saúde" (Ferraz, 2017), ela desativa o desejo de vingança e instaura uma aceitação, um apaziguamento em relação à vida:

Estar livre do ressentimento, estar esclarecido sobre o ressentimento - que sabe até que ponto também nisso devo ser grato à minha longa enfermidade! [...] Contra isso o doente tem apenas um grande remédio - eu o chamo fatalismo russo, aquele fatalismo sem revolta (Nietzsche, 2008, p. 27- 28, grifo do autor).

Assim, Raskólnikov se entrega e vai para a prisão na Sibéria, acompanhado de Sônia. A punição, olhar paterno que falta tanto a Raskólnikov quanto ao seu criador Dostoiévski, restaura o sentido das ações morais em um mundo vazio, e é mais 
restauração ontológica do que especificamente confissão de culpa. A punição serve como reestabelecimento do sentido do real após o esfacelamento desempenhado pelo homicídio absurdo, e para Raskólnikov serve de salvação do absurdo da mesma forma que o suicídio serve como fuga para Svidrigáilov. A narrativa, portanto, termina com uma esperança de redenção, a descoberta beatífica do amor correspondido, na cena em que a prostituta e o assassino leem a passagem da ressurreição de Lázaro no Evangelho segundo São João e Dostoiévski anuncia a história de uma redenção enquanto Raskólnikov reflete sobre o crime e os sofrimentos do passado (Kehl, 2020).

\section{Considerações finais}

Raskólnikov explora, enquanto personagem, o esfacelamento da moral religiosa e as suas consequências para a sociedade, evidenciando um desconforto que, ainda hoje, é nosso: o desenrolar histórico dos modelos de fundamentação da moralidade. Isso vai da fundamentação transcendente do discurso religioso ao fundamento racional do pensamento iluminista e o cientificismo que lhe é subsequente, mas que, inadvertidamente, vê as suas estruturas racionais e democráticas ruírem lentamente ao longo do século $X X$, dando espaço ao justificado desespero niilista ou suas alternativas ainda mais nefastas, o neofundamentalismo midiático ou o consumismo materialista.

Nosso protagonista encontra no vazio não a possibilidade de criação, como especulava a filosofia nietzschiana, mas o desespero com o qual nos atazana o Existencialismo: somos absolutamente livres, e isso é terrível. Por outro lado, a profundidade intelectual do personagem em suas reflexões sobre arrependimento, culpa, individualismo e altruísmo nos impede de condená-lo de forma tácita e maniqueísta, como um perverso ou um narcisista, pois suas reflexões nos causam uma familiar estranheza, para recuperar o termo de Freud, que é o reconhecimento de um certo desconforto, o de identificar-se com ele, o de que alguns de seus pensamentos já possam ter nos ocorrido em algum momento. Ele nos obriga a reconhecer que o desejo que malfadadamente realiza já foi sentido por cada um de nós e imediatamente recalcado infinitas e cotidianas vezes. Não necessariamente o impulso para o crime - para não ofendermos almas mais delicadas -, mas pelo menos o questionamento sobre a arbitrariedade e a superficialidade dos valores sobre os quais fundamos nossa personalidade moral, nossos vínculos familiares e nossas estruturas sociais.

Assim como nós, Raskólnikov não se conhece, pois, apesar de sua racionalização niilista, sofre com a culpa em relação a seus sentimentos altruístas e ao seu bom caráter. Como se, ciente de habitar um mundo perverso, desejasse ser ainda mais perverso que ele, o que tornaria sua existência não apenas mais confortável como também mais promissora. Disposição esta que esbarra, malogradamente, na 
sensibilidade perceptiva de sua alma de intelectual. Sua angústia só encontra placebo a partir da influência de Sonietchka, que o tira de sua posição ressentida quando o obriga a se entregar e a ideia de que ele não é especial ou distinto dos outros homens, ou seja, quando se reconhece homem de massa, insignificante como qualquer outro de seus companheiros de prisão, e se apazigua com a constatação de que ninguém é melhor, de que não existem homens grandiosos, justamente porque, em um mundo sem sentido, não há mais um critério com o qual medir as existências. Aqui se faz presente uma das aproximações mais frutíferas entre Nietzsche e Dostoiévski, além desta do ressentimento que viemos explorando até aqui, que é a do Niilismo (Araldi, 2004; Paschoal, 2015). Tal viés não foi desenvolvido aqui por conta, por um lado, do foco de nosso texto no ressentimento incluindo os aportes psicanalíticos possíveis a esta discussão e, por outro, por conta da importância do tema que não poderia ser tratado aqui de forma precipitada e superficial, uma vez que a complexidade do tema demandaria, para ser abordada adequadamente, de outro texto, ficando, assim, como elemento instigador de outros estudos. Ainda assim, podemos apontar que a superação do niilismo através da religiosidade ingênua e arcaica não possa ser entendida como a resposta final de Dostoiévski ao abismo de sentido que ele tão bem percebeu e descreveu em suas obras. Em carta de 1854, ele mesmo confessa: "Eu sou um filho do século, filho da descrença e da dúvida; assim tenho sido até hoje e o serei até o fim dos meus dias" (Dostoiévski, [1854] apud Bezerra, 2009, p. 13). A religião de Dostoiévski, a despeito de seus personagens, ainda é a nossa, o mais profundo abismo de si mesmo.

\section{Referências}

Araldi, C. L. (2004). Niilismo, Criação, Aniquilamento: Nietzsche e a Filosofia dos Extremos. Ijuí, RS: Unijuí Editora.

Bakhtin, M. (1981). Problemas da poética de Dostoiévski. Tradução de Paulo Bezerra. Rio de Janeiro: Forense-Universitária.

Bezerra, P. (2009). Nas Sendas de Crime e Castigo. In: Dostoiévski, Fiódor. Crime e Castigo. Tradução de Paulo Bezerra. 6. ed. São Paulo: Editora 34, p. 7-13.

Dostoiévski, F. (2009). Crime e Castigo. Tradução de Paulo Bezerra. São Paulo: Editora 34.

Ferraz, M. C. F. (2017). Nietzsche: O Bufão dos Deuses. São Paulo: n-1 edições.

Freud, S. (2018). Arte, literatura e os artistas. Obras Incompletas de Sigmund Freud. Tradução de Ernani Chaves. Belo Horizonte: Editora Autêntica.

Giacoia Junior, O. (2001). Nietzsche como psicólogo. São Leopoldo: Unisinos.

Giacoia Junior, O. (2005). Sonhos e Pesadelos da Razão Esclarecida: Nietzsche e a Modernidade. Passo Fundo: UPF.

Kehl, M. R. (2020). Ressentimento. São Paulo: Boitempo. 
Machado, R. (2001). Nietzsche e a verdade. Rio de Janeiro: Rocco.

Marton, S. (2018). O ressentimento como artifício do ódio e da Vingança. Entrevista concedida a Márcia Junges. IHU Online: Revista do Instituto Humanitas Unisinos. São Leopoldo, ed. 529, n. 127, p. 32-36. Disponível em: http://www.ihuonline. unisinos.br/artigo/7439-o-ressentimento-como-artificio-do-odio-e-da-vinganca. Acesso em: 08 jan. 2021.

Nietzsche, F. W. (2004). Genealogia da Moral: Uma polêmica. [Zur Genealogie der Moral]. Tradução de Paulo César de Souza. São Paulo: Companhia das Letras.

Nietzsche, F. W. (2008). Ecce Homo: como alguém se torna o que é. [Ecce Homo: Wie man wird, was man ist]. Tradução de Paulo César de Souza. São Paulo: Companhia das Letras.

Nietzsche, F. W. (2017). Crepúsculo dos Ídolos: ou Como se filosofa com o martelo. [Götzen-Dammerung oder Wie man mit dem Hammer philosophiert]. Tradução de Paulo César de Souza. São Paulo: Companhia das Letras, 2017.

Onfray, M. (2005). Traité d'Athéologie. Paris: Edition Grasset \& Fasquelle.

Pondé, L. F. (2003). Crítica e profecia: A filosofia da religião em Dostoievski. São Paulo: Editora 34.

Paschoal, A. E. (2010). Dostoiévski e Nietzsche: anotações em torno do "homem do ressentimento”. Estudos Nietzsche, Curitiba, 1, (1), 181-198. DOI: https://doi. org/10.7213/ren.v1i1.22568

Paschoal, A. E. (2015). Vestígios de Dostoiévski na Correspondência de Nietzsche. Estudos Nietzsche, Curitiba, 6(2), 310-316.

Silveira, H. (1970). Três ensaios sobre Dostoievski. São Paulo: Martins. 